\title{
Prostaglandin secretion by endometrium of pregnant and cyclic cattle at Day 17 after oestrus in response to in-vitro heat stress*
}

\author{
D. J. Putney, T. S. Gross and W. W. Thatcher \\ Department of Dairy Science, Institute of Food and Agricultural Sciences, University of Florida, \\ Gainesville, Florida 32611, U.S.A.
}

\begin{abstract}
Summary. Bilateral perifusion devices were utilized to measure prostaglandin F- $2 \alpha$ (PGF) secretion by bovine endometrium in response to in-vitro heat stress. Tissues were collected at Day 17 after oestrus from cyclic $(N=4)$ and pregnant $(N=5)$ cows, placed into 3 perifusion devices, perifused $(3 \mathrm{ml} / 10 \mathrm{~min}$, Krebs-Ringer-bicarbonate [KRB]) for $5 \mathrm{~h}$, and fractions were collected every $10 \mathrm{~min}$. Endometrial tissues within each device were subjected to a different temperature and oxytocin ( 1 i.u./ml KRB) treatment sequence: (1) control-oxytocin: $1 \mathrm{~h}$ at $39^{\circ} \mathrm{C} ; 2 \mathrm{~h}$ at $39^{\circ} \mathrm{C}, 0.5 \mathrm{~h}$ at $39^{\circ} \mathrm{C}$ with oxytocin, $0.5 \mathrm{~h}$ at $39^{\circ} \mathrm{C}$ and $1 \mathrm{~h}$ at $39^{\circ} \mathrm{C}$; (2) heat-oxytocin: $1 \mathrm{~h}$ at $39^{\circ} \mathrm{C}, 2 \mathrm{~h}$ at $42^{\circ} \mathrm{C}$, $0.5 \mathrm{~h}$ at $42^{\circ} \mathrm{C}$ with oxytocin, $0.5 \mathrm{~h}$ at $42^{\circ} \mathrm{C}$ and $1 \mathrm{~h}$ at $39^{\circ} \mathrm{C}$; (3) heat-KRB: $1 \mathrm{~h}$ at $39^{\circ} \mathrm{C}$, $2 \mathrm{~h}$ at $42^{\circ} \mathrm{C}, 0.5 \mathrm{~h}$ at $42^{\circ} \mathrm{C}, 0.5 \mathrm{~h}$ at $42^{\circ} \mathrm{C}$ and $1 \mathrm{~h}$ at $39^{\circ} \mathrm{C}$. Regardless of reproductive status, heat stress induced a rapid increase $(P<0.01)$ in PGF secretion rates. Oxytocin induced an increase $(P<0.01)$ in PGF secretion for endometrium from cyclic cows regardless of temperature. Endometria from pregnant cows did not respond to oxytocin when perifused at $39^{\circ} \mathrm{C}$. However, PGF secretion rates from endometrium of pregnant cows increased $(P<0.01)$ in response to oxytocin when perifused under heat stress conditions. Increased PGF secretion rates and responsiveness to oxytocin for endometria from pregnant cows in response to heat stress suggests that the ability of the conceptus to inhibit uterine PGF- $2 \alpha$ synthesis may be compromised during early pregnancy when cattle are subjected to high ambient temperatures.
\end{abstract}

Keywords: endometrium; heat stress; prostaglandin; cattle; oxytocin

\section{Introduction}

Environmental heat stress often results in transient infertility in cattle (Gwazdauskas et al., 1973; Ingraham et al., 1974; Thatcher, 1974; Badinga et al., 1985). The early bovine embryo (Days 1-7 of development) is extremely sensitive to the harmful effects of maternal hyperthermia in that the frequency of non-viable, abnormal and retarded embryos is increased (Putney et al., 1986). In addition, maternal heat stress between Days 8 and 16 after insemination reduces conceptus weight resulting in a trend towards increased pregnancy failure in beef cattle (Biggers et al., 1987). In-vitro heat stress of conceptuses recovered at Day 17 of pregnancy induced a marked decrease in the synthesis and secretion of proteins into culture medium (Putney et al., 1987). Since heat stress retards development and reduces protein synthetic capacity of conceptuses, it is possible that embryonic mortality may result, in part, from failure of conceptuses to produce adequate amounts of antiluteolytic biochemical signals necessary to maintain a functional corpus luteum (CL).

*Reprint requests to $\mathrm{Dr} \mathrm{W}$. W. Thatcher. 
There is considerable evidence that the uterine luteolysin in cattle is prostaglandin (PG) F-2 $\alpha$ (Lauderdale, 1974; Thatcher et al., 1984). Exogenous administration of PGF-2 $\alpha$ will induce luteolysis (Lauderdale, 1974; Thatcher \& Chenault, 1976) while passive immunization against PGF-2 $\alpha$ extends corpus luteum life-span (Fairclough et al., 1981). Furthermore, increased PGF- $2 \alpha$ concentrations have been demonstrated in uterine flushings (Bartol et al., 1981), uterine venous plasma (Nancarrow et al., 1973) and in endometrial tissues (Thatcher et al., 1984) before luteolysis. The pre-attachment bovine conceptus secretes an array of proteins that are believed to be involved in attenuating the sequence of events leading to luteolysis (Bartol et al., 1985; Knickerbocker et al., $1986 a)$. These antiluteolytic proteins may act locally on the gravid uterine horn to alter the synthesis and release of PGF- $2 \alpha$ from the endometrium, possibly by stimulating the production of an intracellular endometrial inhibitor of prostaglandin synthesis (Gross et al., 1988a).

Thermal stress between Days 8 and 16 after insemination increased concentrations of 13,14dihydro-15-keto PGF-2 $\alpha$ (PGFM), a metabolite of PGF-2 $\alpha$, in the peripheral circulation of gilts (Wettemann et al., 1984). Additionally, Lewis et al. (1984) reported that pre-partum heat stress increased the concentrations of PGFM during the post-partum period in dairy cattle. Increased concentrations of systemic PGFM may reflect greater uterine secretion of PGF-2 $\alpha$ in response to heat stress. The present study examined whether in-vitro heat stress would increase the secretion of PGF- $2 \alpha$ by perifused endometrial tissue from pregnant and cyclic cattle at Day 17 after oestrus. Alterations in uterine PGF- $2 \alpha$ secretion may exert pronounced effects on CL life-span and therefore maintenance of pregnancy.

\section{Materials and Methods}

Materials. Harvard infusion pump systems were purchased from Harvard Apparatus (Dover, MA, U.S.A.). Oxytocin and radioinert PGF-2 $\alpha$ were purchased from Sigma Chemical Company (St Louis, MO, U.S.A.). Radiolabelled $\left[5,6,8,9,11,12,14,15-{ }^{3} \mathrm{H}\right] \mathrm{PGF}-2 \alpha$ (sp. act. $\simeq 160-180 \mathrm{Ci} / \mathrm{mmol}$ ) was purchased from Amersham Corporation (Arlington Heights, IL, U.S.A.). Rabbit antiserum to PGF- $2 \alpha$ was provided by Dr T. G. Kennedy (University of Western Ontario, Canada).

Collection of uterine endometrium. Beef cattle (Angus or Brangus) were observed for behavioural oestrus and were mated by natural service $(\mathrm{N}=5)$ or not mated $(\mathrm{N}=4)$. Cattle were slaughtered on Day 17 after oestrus and reproductive tracts were recovered and flushed with Minimal Essential Medium (MEM, $40 \mathrm{ml}$ ) to collect conceptus tissue and confirm pregnancy. The uterine horn ipsilateral to the $C L$ was opened longitudinally along the antimesometrial border and endometrium was dissected free from myometrium over a surface area of $6-7 \mathrm{~cm}^{2}$. Each endometrial sample was placed into sterile Krebs'-Ringer bicarbonate solution (KRB) which was gassed with $\mathrm{O}_{2}: \mathrm{CO}_{2}(95: 5 \mathrm{v} / \mathrm{v})$, washed twice with fresh $\mathrm{KRB}$, and dissected into three pieces of $2 \mathrm{~cm}^{2}$ each.

In-vitro perifusion of endometrium. Each of the three endometrial samples was placed into a bilateral perifusion device which allows for separation of myometrial and luminal surfaces of endometrium so that each side can be perifused separately in a $0.5 \mathrm{ml}$ hemi-chamber (Lacroix \& Kann, 1983). Tissue was stretched and anchored into each device with the aid of 4 needles. Each chamber was placed into a water bath $\left(39^{\circ} \mathrm{C}\right)$, attached to dual 60 -ml syringes containing $\mathrm{KRB}$, and perifused at a rate of $3 \mathrm{ml} / 10 \mathrm{~min}$ for $5 \mathrm{~h}$ using a Harvard infusion pump system. Fractions $(3 \mathrm{ml})$ were collected every $10 \mathrm{~min}$ for a total of 30 fractions.

Each of the 3 endometrial perifusion preparations within each cow was subjected to a different temperature and oxytocin ( $1 \mathrm{i} . \mathrm{u} . / \mathrm{ml} \mathrm{KRB})$ treatment sequence: (1) control-oxytocin: $1 \mathrm{~h}$ at $39^{\circ} \mathrm{C}, 2 \mathrm{~h}$ at $39^{\circ} \mathrm{C}, 0.5 \mathrm{~h}$ at $39^{\circ} \mathrm{C}$ with oxytocin, $0.5 \mathrm{~h}$ at $39^{\circ} \mathrm{C}$ and $1 \mathrm{~h}$ at $39^{\circ} \mathrm{C}$, (2) heat-oxytocin: $1 \mathrm{~h}$ at $39^{\circ} \mathrm{C}, 2 \mathrm{~h}$ at $42^{\circ} \mathrm{C}, 0.5 \mathrm{~h}$ at $42^{\circ} \mathrm{C}$ with oxytocin, $0.5 \mathrm{~h}$ at $42^{\circ} \mathrm{C}$ and $\mathrm{l} \mathrm{h}$ at $39^{\circ} \mathrm{C}$; (3) heat-KRB: $1 \mathrm{~h}$ at $39^{\circ} \mathrm{C}, 2 \mathrm{~h}$ at $42^{\circ} \mathrm{C}, 0.5 \mathrm{~h}$ at $42^{\circ} \mathrm{C}$ with no oxytocin, $0.5 \mathrm{~h}$ at $42^{\circ} \mathrm{C}$ and $1 \mathrm{~h}$ at $39^{\circ} \mathrm{C}$. Temperature treatments were imposed on endometrium by placing perifusion devices in water baths maintained at 39 or $42^{\circ} \mathrm{C}$ and perifusing tissues with $\mathrm{KRB}$ maintained at 39 or $42^{\circ} \mathrm{C}$.

Measurement of PGF-2a. Fractions were analysed for PGF-2 $\alpha$ using a radioimmunoassay (RIA) procedure (Knickerbocker $e t$ al., 1986b) modified to use an antibody characterized by Kennedy (1985) and validated by Gross $e t$ al. (1988b) for analysis of unextracted medium. Cross-reactivities of the PGF-2 $\alpha$ antiserum with other prostaglandins were $94 \%$ for PGF-1 $\alpha, 2.4 \%$ for PGE-2, $<1 \%$ for 6-keto PGF-1 $\alpha$, and $<0.1 \%$ for PGFM, PGE-1 and arachidonic acid. Due to the high cross-reactivity with PGF-1 $\alpha$, PGF- $2 \alpha$ measurements are defined as PGF. Inter- and intra-assay coefficients of variation were $12 \cdot 2 \%$ and $9 \cdot 7 \%$, respectively.

Statistical analysis. Data were analysed by Least Squares Analysis of Variance using the General Linear Models procedure of the Statistical Analysis System (SAS, 1985). Prostaglandin secretion rates of luminal, myometrial or 
luminal + myometrial sides of endometrium were analysed statistically for the following perifusion treatment periods: (1) $1 \mathrm{~h}$ before heat stress, (2) $2 \mathrm{~h}$ before oxytocin, (3) $0.5 \mathrm{~h}$ with or without oxytocin, (4) $0.5 \mathrm{~h}$ after oxytocin, and (5) $1 \mathrm{~h}$ after heat stress (Fig. 1). The means \pm s.e. for each period, presented in Tables 2, 3 and 4, are means for the series of 10-min measurements made within each period. The statistical model is presented in Table 1, and analyses for total (luminal + myometrial sides of endometrium) PGF secretion for periods 2 and 3 are also presented in Table 1 .

Table 1. Least squares analyses of variance of total (luminal + myometrial surfaces) endometrial PGF secretion rates for thermoneutral $v s$ heat stress (period $2 ; 2 \mathrm{~h}$ at 39 or $42^{\circ} \mathrm{C}$ ) and oxytocin (period $3 ; 0.5 \mathrm{~h}$ at $39^{\circ} \mathrm{C}$ with oxytocin, or $42^{\circ} \mathrm{C}$ with or without oxytocin) treatments

\begin{tabular}{|c|c|c|c|c|}
\hline \multirow[b]{3}{*}{ Sources of variation ${ }^{d}$} & \multicolumn{4}{|c|}{ Perifusion treatment periods } \\
\hline & \multicolumn{2}{|r|}{2} & \multicolumn{2}{|r|}{2} \\
\hline & $\mathrm{df}$ & $\mathrm{MS} \times 10^{-4}$ & $\mathrm{df}$ & $\mathrm{MS} \times 10^{-4}$ \\
\hline Status ${ }^{\mathrm{a}}$ & 1 & $2487 \cdot 9^{*}$ & 1 & $1827 \cdot 0^{* *}$ \\
\hline Cow (status) & 7 & $448 \cdot 2^{* *}$ & 7 & $146 \cdot 9 * *$ \\
\hline Treatment $^{\mathrm{b}}$ & 2 & $1957 \cdot 8 * *$ & 2 & $776 \cdot 9^{*}$ \\
\hline Status $\times$ treatment & 2 & 6.4 & 2 & $32 \cdot 4$ \\
\hline Cow (status) $\times$ treatment & 10 & $16 \cdot 6$ & 10 & $176 \cdot 0$ \\
\hline Time $^{c}$ & 11 & $104 \cdot 1 * *$ & 2 & $48 \cdot 3$ \\
\hline Status $\times$ time & 11 & $27 \cdot 2^{*}$ & 2 & $16 \cdot 5$ \\
\hline Treatment $\times$ time & 22 & $30 \cdot 1 * *$ & 4 & $30 \cdot 8$ \\
\hline Status $\times$ treatment $\times$ time & 22 & $15 \cdot 1$ & 3 & $35 \cdot 4$ \\
\hline Residual & 162 & $13 \cdot 1$ & 22 & $37 \cdot 2$ \\
\hline
\end{tabular}

${ }^{a}$ Status of endometrium: cyclic $v s$ pregnant.

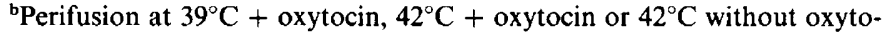
cin.

'Perifusion for 10-min time periods.

${ }^{\mathrm{d}} \mathrm{df}=$ degrees of freedom; MS $=$ mean squares; ${ }^{*} P<0.05,{ }^{* *} P<0.01$.

\section{Results}

Endometrial tissues remained viable throughout perifusion as indicated by sustained PGF release into KRB solution throughout the duration of perifusion (Fig. 1). Mean secretion rates of total (luminal + myometrial surfaces) PGF when KRB was perifused across tissues maintained at thermoneutral temperatures (treatment period 1$)$ were $46 \%$ lower $(P<0.01)$ for endometrium from pregnant compared to cyclic cows $(678 \pm 34$ vs $1282 \pm 128 \mathrm{pg} / 10 \mathrm{~min}$; Table 2$)$.

Endometrial secretion of PGF occurred primarily from the luminal surface of tissues for each reproductive status, but the magnitude of the difference between sides was less $(P<0.01)$ for pregnant $(181 \mathrm{pg} / 10 \mathrm{~min})$ than for cyclic $(482 \mathrm{pg} / 10 \mathrm{~min})$ cows (Tables 3 and 4). Mean PGF secretion rates by tissues maintained at thermoneutral temperature (treatment period 1) were $77 \%$ higher $(P<0.05)$ for luminal compared to myometrial surfaces of endometrium from pregnant cows $(427 \pm 14$ vs $241 \pm 19 \mathrm{pg} / 10 \mathrm{~min})$ and $120 \%$ higher $(P<0.01)$ for cyclic cows $(884 \pm 82$ vs $402 \pm 38 \mathrm{pg} / 10 \mathrm{~min})$. Although myometrial surfaces secreted less PGF than did luminal surfaces, PGF secretion responses to temperature and oxytocin treatments were parallel between sides (Tables 3 and 4). Therefore, PGF responses detected in luminal and myometrial KRB perfusates were combined to assess total PGF secretion rates by endometrium in response to heat stress and oxytocin challenge (Fig. 1; Tables 1 and 2). 


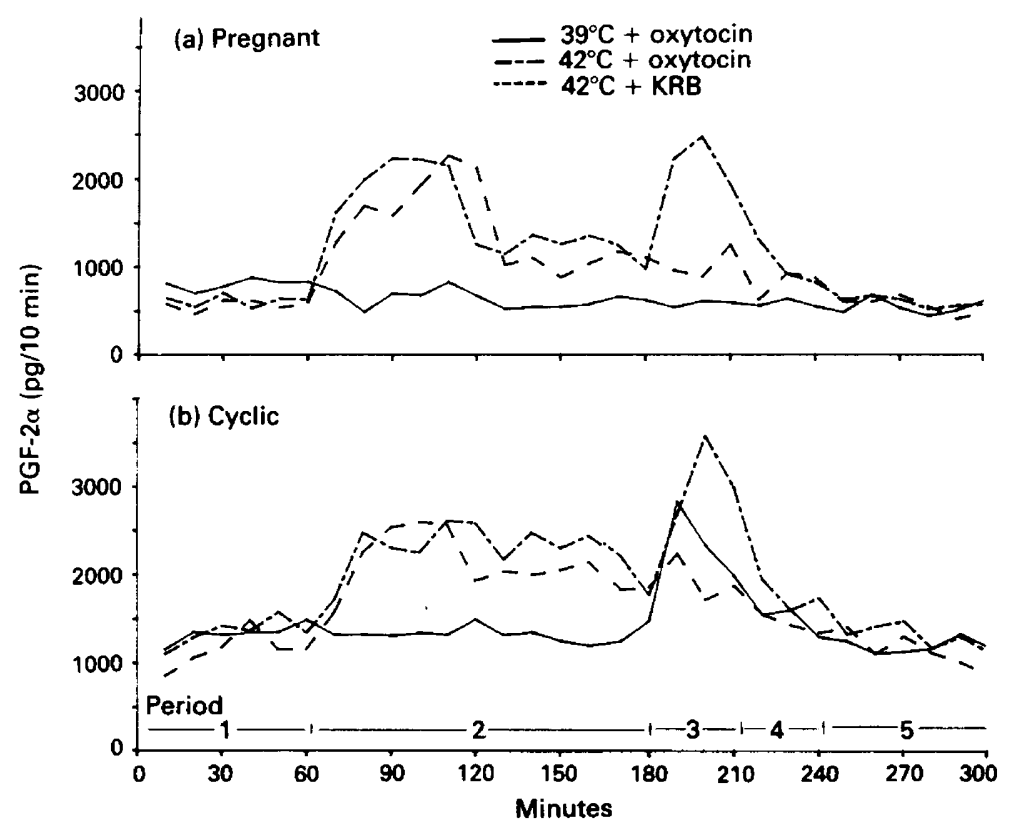

Fig. 1. Total (luminal + myometrial surfaces) secretion rate $(\mathrm{pg} / 10 \mathrm{ml} \mathrm{KRB})$ of PGF by endometrium, of (a) pregnant and (b) cyclic cows, perifused at $39^{\circ} \mathrm{C}$ with an oxytocin challenge $(-)$ or at $42^{\circ} \mathrm{C}$ with $(---)$ or without $(--)$ an oxytocin challenge. Perifusion periods analysed were: (1) $1 \mathrm{~h}$ at $39^{\circ} \mathrm{C}$, (2) $2 \mathrm{~h}$ at 39 or $42^{\circ} \mathrm{C}$, (3) $0.5 \mathrm{~h}$ at $39^{\circ} \mathrm{C}$ with oxytocin or $42^{\circ} \mathrm{C}$ with or without oxytocin, (4) $0.5 \mathrm{~h}$ at 39 or $42^{\circ} \mathrm{C}$, and (5) $1 \mathrm{~h}$ at $39^{\circ} \mathrm{C}$.

Table 2. Total (luminal + myometrial surfaces) endometrial secretion rates (mean \pm s.e.) of PGF (pg/10 min) into KRB during perifusion at the following treatment periods: (1) $1 \mathrm{~h}$ at $39^{\circ} \mathrm{C}$, (2) $2 \mathrm{~h}$ at 39 or $42^{\circ} \mathrm{C}$, (3) $0.5 \mathrm{~h}$ at $39^{\circ} \mathrm{C}$ with oxytocin or $42^{\circ} \mathrm{C}$ with or without oxytocin, (4) $0.5 \mathrm{~h}$ at 39 or $42^{\circ} \mathrm{C}$, and (5) $1 \mathrm{~h}$ at $39^{\circ} \mathrm{C}$

\begin{tabular}{|c|c|c|c|c|c|}
\hline \multirow[b]{2}{*}{ Groups } & \multicolumn{5}{|c|}{ Perifusion treatment period } \\
\hline & $1^{2}$ & $2^{b}$ & $3^{b}$ & $4^{a, c}$ & $5^{a}$ \\
\hline \multicolumn{6}{|l|}{ Pregnant $(\mathrm{N}=5)$} \\
\hline $39^{\circ} \mathrm{C}$-oxytocin & $857 \pm 87$ & $609 \pm 33$ & $530 \pm 43$ & $541 \pm 54$ & $505 \pm 50$ \\
\hline $42^{\circ} \mathrm{C}$-oxytocin & $618 \pm 43$ & $1572 \pm 96$ & $2300 \pm 265$ & $1005 \pm 153$ & $581 \pm 51$ \\
\hline $42^{\circ} \mathrm{C}-\mathrm{KRB}$ & $560 \pm 34$ & $1465 \pm 114$ & $870 \pm 87$ & $885 \pm 67$ & $523 \pm 35$ \\
\hline \multicolumn{6}{|l|}{ Cyclic $(N=4)$} \\
\hline $39^{\circ} \mathrm{C}$-oxytocin & $1337 \pm 148$ & $1323 \pm 100$ & $2352 \pm 300$ & $1483 \pm 159$ & $1166 \pm 86$ \\
\hline $42^{\circ} \mathrm{C}$-oxytocin & $1316 \pm 156$ & $2323 \pm 153$ & $3024 \pm 344$ & $1731 \pm 177$ & $1104 \pm 107$ \\
\hline $42^{\circ} \mathrm{C}-\mathrm{KRB}$ & $1193 \pm 105$ & $2124 \pm 165$ & $2040 \pm 261$ & $1595 \pm 128$ & $1199 \pm 69$ \\
\hline
\end{tabular}

${ }^{a} P<0.01$ for status and cow (status).

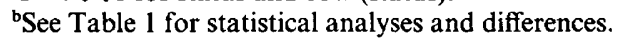

${ }^{\mathrm{c}} P<0.01$ for treatment. 
Before the application of heat stress (treatment period 1), PGF secretion rates by endometria within each reproductive status were similar among treatment groups (Table 2). Elevation of perifusion temperature from 39 to $42^{\circ} \mathrm{C}$ stimulated PGF secretory capacity of endometrium regardless of reproductive status (Table 2). Overall secretion rates of PGF during the first $2 \mathrm{~h}$ of heat stress (treatment period 2$)$ were $68 \%$ greater $(P<0.01)$ for cyclic $(2223 \pm 96 \mathrm{vs} 1323 \pm 100 \mathrm{pg} / 10 \mathrm{~min})$ and $149 \%$ greater $(P<0.01)$ for pregnant $(1518 \pm 65 v s 609 \pm 33 \mathrm{pg} / 10 \mathrm{~min})$ endometrium. Heat stress induced a rapid (within $10 \mathrm{~min}$ ) release of $P G F$ by endometrium from pregnant and cyclic cows. However, the response was not sustained by pregnant endometrium, and declined precipitously within $1 \mathrm{~h}$ after initiation of thermal stress (Fig. 1).

Table 3. Secretion rates (mean \pm s.e.) of PGF ( $\mathrm{pg} / 10 \mathrm{~min}$ ) into KRB by luminal surfaces of endometrium perifused during the following treatment periods: (1) $1 \mathrm{~h}$ at $39^{\circ} \mathrm{C}$, (2) $2 \mathrm{~h}$ at 39 or $42^{\circ} \mathrm{C}$, (3) $0.5 \mathrm{~h}$ at $39^{\circ} \mathrm{C}$ with oxytocin or $42^{\circ} \mathrm{C}$ with or without oxytocin, (4) $0.5 \mathrm{~h}$ at 39 or $42^{\circ} \mathrm{C}$, and (5) $1 \mathrm{~h}$ at $39^{\circ} \mathrm{C}$

\begin{tabular}{|c|c|c|c|c|c|c|}
\hline \multirow[b]{2}{*}{ Groups } & \multicolumn{6}{|c|}{ Perifusion treatment period } \\
\hline & $1^{\mathbf{a}}$ & $2^{b}$ & & $3^{c}$ & $4^{\mathrm{d}}$ & $5^{e}$ \\
\hline \multicolumn{7}{|l|}{ Pregnant $(N=5)$} \\
\hline $39^{\circ} \mathrm{C}$-oxytocin & $478 \pm 42$ & $386 \pm$ & 18 & $343 \pm 33$ & $362 \pm 35$ & $337 \pm 22$ \\
\hline $42^{\circ} \mathrm{C}$-oxytocin & $435 \pm 29$ & $1080 \pm$ & 55 & $1332 \pm 97$ & $613 \pm 67$ & $391 \pm 31$ \\
\hline $42^{\circ} \mathrm{C}-\mathrm{KRB}$ & $354 \pm 32$ & $869 \pm$ & 69 & $563 \pm 77$ & $537 \pm 58$ & $327 \pm 33$ \\
\hline \multicolumn{7}{|l|}{ Cyclic $(N=4)$} \\
\hline $39^{\circ} \mathrm{C}-$ oxytocin & $896 \pm 101$ & $955 \pm$ & 62 & $1594 \pm 222$ & $1088 \pm 118$ & $879 \pm 77$ \\
\hline $42^{\circ} \mathrm{C}$ - oxytocin & $948 \pm 93$ & $1410 \pm$ & 78 & $1952 \pm 127$ & $1144 \pm 83$ & $914 \pm 93$ \\
\hline $42^{\circ} \mathrm{C}-\mathrm{KRB}$ & $809 \pm 78$ & $1362 \pm$ & 99 & $973 \pm 81$ & $1043 \pm 129$ & $907 \pm 78$ \\
\hline
\end{tabular}

${ }^{a} P<0.01$ for status and cow (status).

${ }^{\mathrm{b}} P<0.05$ for status and $P<0.01$ for cow (status), treatment, cow (status) $\times$ treatment and time and treatment $\times$ time.

${ }^{c} P<0.01$ for status and treatment and $P<0.05$ for cow (status).

${ }^{\mathrm{d} P}<0.01$ for status, cow (status) and treatment.

${ }^{\mathrm{e}} P<0.01$ for status and cow (status).

Table 4. Secretion rates (mean \pm s.e.) of PGF $(\mathrm{pg} / 10 \mathrm{~min})$ into KRB by myometrial surfaces of endometrium perifused during the following treatment periods: (1) $1 \mathrm{~h}$ at $39^{\circ} \mathrm{C},(2) 2 \mathrm{~h}$ at 39 or $42^{\circ} \mathrm{C},(3) 0.5 \mathrm{~h}$ at $39^{\circ} \mathrm{C}$ with oxytocin or $42^{\circ} \mathrm{C}$ with or without oxytocin, (4) $0.5 \mathrm{~h}$ at 39 or $42^{\circ} \mathrm{C}$, and (5) $1 \mathrm{~h}$ at $39^{\circ} \mathrm{C}$

\begin{tabular}{lccccc}
\hline \multicolumn{5}{c}{ Perifusion treatment period } \\
\cline { 2 - 6 } Groups & $1^{\mathrm{a}}$ & $2^{\mathrm{b}}$ & $3^{\mathrm{c}}$ & $4^{\mathrm{d}}$ & $5^{\mathrm{e}}$ \\
\hline Pregnant $(\mathrm{N}=5)$ & & & & & \\
$39^{\circ} \mathrm{C}-$ oxytocin & $325 \pm 43$ & $223 \pm 15$ & $232 \pm 15$ & $213 \pm 21$ & $200 \pm 15$ \\
$42^{\circ} \mathrm{C}$-oxytocin & $192 \pm 14$ & $494 \pm 41$ & $863 \pm 151$ & $404 \pm 68$ & $205 \pm 11$ \\
$42^{\circ} \mathrm{C}-\mathrm{KRB}$ & $208 \pm 16$ & $597 \pm 45$ & $351 \pm 51$ & $337 \pm 56$ & $203 \pm 12$ \\
Cyclic $(\mathrm{N}=4)$ & & & & & \\
$39^{\circ} \mathrm{C}-$ oxytocin & $434 \pm 47$ & $368 \pm 17$ & $800 \pm 101$ & $393 \pm 51$ & $304 \pm 14$ \\
$42^{\circ} \mathrm{C}-$ oxytocin & $417 \pm 63$ & $914 \pm 76$ & $1172 \pm 199$ & $683 \pm 108$ & $381 \pm 3$ \\
$42^{\circ} \mathrm{C}-\mathrm{KRB}$ & $356 \pm 37$ & $763 \pm 66$ & $960 \pm 148$ & $389 \pm 35$ & $293 \pm 33$ \\
\hline
\end{tabular}

${ }^{2} P<0.01$ for status and cow (status).

${ }^{\mathrm{b}} P<0.05$ for status, time and status $\times$ time and $P<0.01$ for cow (status), treatment and cow (status) $\times$ treatment.

${ }^{c} P<0.01$ for status, cow (status) and treatment.

${ }^{d} P<0.05$ for status and $P<0.01$ for cow (status) and treatment.

${ }^{\mathrm{e}} P<0.01$ for status and $P<0.05$ for cow (status). 
Perifusion of KRB supplemented with oxytocin (treatment period 3) induced a rapid $164 \%$ increase $(P<0.01)$ in secretion of PGF by heat-stressed pregnant endometrium $(2300 \pm 265$ vs $870 \pm 87 \mathrm{pg} / 10 \mathrm{~min})$. In contrast, pregnant endometrium perifused at $39^{\circ} \mathrm{C}$ did not respond to oxytocin treatment with increased PGF release (Table 2). Cyclic endometrium, regardless of perifusion temperature, increased the rate of PGF secretion in response to oxytocin challenge; a $48 \%$ increase $(P<0.05)$ in PGF secretion by heat-stressed tissues $(3024 \pm 344 v s 2040 \pm 261 \mathrm{pg} / 10 \mathrm{~min})$ and a $77 \%$ increase $(P<0.05)$ by thermoneutral tissues $(2353 \pm 300 v s 1323 \pm 100 \mathrm{pg} / 10 \mathrm{~min})$ was detected. At the conclusion of oxytocin perifusion, secretion rates of PGF declined rapidly and returned to pre-oxytocin rates of secretion within $30 \mathrm{~min}$ of perfusion with KRB (treatment period 4; Table 2, Fig. 1).

At the conclusion of heat stress, a reduction in incubation temperature from 42 to $39^{\circ} \mathrm{C}$ (treatment period 5) reduced $(P<0.01)$ endometrial prostaglandin secretion rates. Overall mean secretion rates of PGF into KRB by tissues within each reproductive status were similar among treatment groups in period 5 (Fig. 1, Table 2).

\section{Discussion}

Establishment of pregnancy in cattle is dependent upon interactions between antiluteolytic and luteolytic factors produced by the periattachment conceptus and uterine endometrium, respectively. Maintenance of luteal function in pregnant cattle is associated with diminished secretion of PGF-2 $\alpha$ during the expected period of luteolysis (Thatcher et al., 1984; Gross et al., 1988b). Likewise, the release of PGF-2 $\alpha$ from the uterus in response to oestrogen (Thatcher et al., 1984) and oxytocin (Lafrance \& Goff, 1985) is attenuated during early pregnancy. Results from the present study using endometrial perifusions confirm that endometrial secretion of PGF is reduced during early pregnancy in cattle.

Heat stress induced a rapid increase in endometrial secretion rates of PGF by luminal and myometrial surfaces for pregnant and cyclic cows. Increased PGF synthetic capacity of endometrium exposed to heat stress may be due to heat-induced alterations in endometrial cellular membranes resulting in increased mobilization of substrate for prostaglandin biosynthesis. The primary cellular site for the action of heat damage on tissues is membranes (Bowler et al., 1973; Hahn, 1982). Exposure to high ambient temperature is accompanied by alterations in membrane lipid composition (Anderson \& Parker, 1982) as well as increases in membrane fluidity, phospholipase activity and phosphoinositide turnover (Calderwood et al., 1987). Heat-induced increases in the turnover of membrane phospholipids and release of fatty acids, such as arachidonic acid, may provide substrates for prostaglandin synthesis (Flint et al., 1986). Arachidonic acid, the principal substrate for PGF-2 $\alpha$ synthesis, is present in large quantities within the bovine endometrium before the time of increased endometrial PGF-2 production and luteolysis (Hansel et al., 1975; Shemesh \& Hansel, 1975). Furthermore, exogenous arachidonic acid will stimulate prostaglandin production by pregnant and cyclic endometrial tissues in vitro (Thatcher et al., 1984). Elevated secretion rate of PGF by heat-stressed pregnant endometrium was not sustained throughout the duration of heatstress perifusion, but declined precipitously within $1 \mathrm{~h}$ after initiation of thermal stress. This decrease in PGF secretion may be due, in part, to a depletion of the intracellular pool of arachidonic acid in endometrial cells of heat-stressed pregnant cows. Perifusion of heat-stressed endometrium of 2 pregnant cows with KRB supplemented with arachidonic acid $(50 \mu \mathrm{g} / \mathrm{ml} \mathrm{KRB})$ resulted in sustained increases in PGF release throughout the period of heat stress (D. J. Putney, T. S. Gross \& W. W. Thatcher, unpublished data).

Similar increases in uterine PGF-2 $\alpha$ secretion in response to heat stress in vitro by endometrial explants from cows at Day 17 of pregnancy have been reported (Putney et al., 1987). Furthermore, in-vivo heat stress of gilts between Days 8 and 16 of pregnancy increased concentrations of PGFM in the peripheral circulation and compromised luteal function, as indicated by reduced plasma concentrations of progesterone during Days 13 through 19 (Hoagland \& Wettemann, 1984; 
Wettemann et al., 1984). In cattle, pre-partum heat stress increases peripheral concentrations of PGFM and reduces CL diameter post-partum (Lewis et al., 1984). Decreased concentrations of progesterone in plasma of gilts and CL size in cattle may be due to heat-induced partial regression of the CL in stressed animals, which may be attributed to greater uterine secretion of PGF- $2 \alpha$ (reflected by greater concentrations of systemic PGFM) in heat stress than in thermoneutral animals. Since maintenance of luteal function in cattle is associated with decreased endometrial PGF-2 $\alpha$ secretion, it is likely that increases in endometrial prostaglandin secretion rate in response to heat stress may compromise CL function, initiate.partial or complete luteal regression and contribute to pregnancy failure.

Endometrium from pregnant cattle, when perifused at thermoneutral temperature, was unable to respond to oxytocin with an increased secretion of PGF, whereas endometria from cyclic cattle responded with an increase in the secretion of PGF. These in-vitro perifusion data are in agreement with previous in-vivo and in-vitro data which demonstrate an attenuated increase in secretion of prostaglandins in response to oxytocin during early pregnancy in cattle (Lafrance \& Goff, 1985; Gross et al., 1988b). However, oxytocin induced a rapid increase in luminal and myometrial secretion rates of PGF by endometrium from heat-stressed pregnant cows as well as tissues of cyclic cows, regardless of perifusion temperature. Such a rapid induction of endometrial prostaglandin secretion by oxytocin has been noted previously in vivo for cyclic cattle (Oyedipe et al., 1984; Lafrance \& Goff, 1985). In vitro, heat stress perturbed the physiological difference between responses of pregnant and cyclic endometrial tissues to oxytocin. Oxytocin-induced secretion rates of PGF for pregnant endometrium exposed to heat stress were similar to those by cyclic endometrium perifused at thermoneutral temperatures.

A heat stress-induced responsiveness of pregnant endometrium to oxytocin may be due in part to increased availability of oxytocin receptors because of alterations in membrane fluidity, or to activation of intracellular signal transduction associated with oxytocin binding to its receptor on the endometrial cell membrane. In particular, oxytocin has been reported to stimulate endometrial prostaglandin synthesis by increasing the hydrolysis of membrane-bound phosphoinositides to diacylglycerol and inositol phosphates with subsequent release of arachidonic acid from diacylglycerol (Flint et al., 1986). Similarly, heat stress has been reported to stimulate membrane phospholipase activity and phosphoinositide turnover (Calderwood et al., 1987) as well as activating cAMP production (Calderwood et al., 1985). Hence, heat stress may potentiate oxytocininduced prostaglandin synthesis by activating oxytocin receptor-induced prostaglandin synthesis by activating oxytocin receptor-mediated second messengers such as inositol phosphates and diacylglycerol.

Alternatively, heat stress may potentiate oxytocin-induced synthesis of endometrial PGF-2 $\alpha$ by altering factors which regulate prostaglandin synthesis during early pregnancy. One ossibility is that heat stress alters activity of an endogenous intracellular endometrial inhibitor of prostaglandin synthesis, the activity of which is normally increased during early pregnancy (Basu \& Kindahl, 1987; Gross et al., 1988a). A heat stress-induced increase in PGF- $2 \alpha$ secretion of pregnant endometrium in response to oxytocin may be a consequence of a decrease in the activity of the prostaglandin inhibitor. Regardless of the mechanism, the sequence of events leading to luteolysis and termination of pregnancy may be initiated by heat stress.

This study was supported in part by USDA Grants 84-CRSR-2-2419 and 85-CRSR-1-1871. We thank Dr T. G. Kennedy for the generous gift of PGF-2 $\alpha$ antisera. This is Journal series no. 8739 of the Florida Agricultural Experimental Station.

\section{References}

Anderson, R.L. \& Parker, R. (1982) Analysis of membrane lipid composition of mammalian cells during the development of thermotolerance. Int. J. Radiat. Res. 42, 57-69. 
Badinga, L., Collier, R.J., Thatcher, W.W. \& Wilcox, C.J. (1985) Effects of climate and management factors on conception rate in dairy cattle in subtropical environments. J. Dairy Sci. 68, 78-85.

Bartol, F.F., Thatcher, W.W., Lewis, G.S., Bliss, E.L., Drost, M. \& Bazer, F.W. (1981) Effect of estradiol$17 \beta$ on PGF and total protein content in bovine uterine flushings and peripheral plasma concentrations of 13,14-dihydro-15-keto PGF-2 $\alpha$. Theriogenology 15, 345-358.

Bartol, F.F., Roberts, R.M., Bazer, F.W., Lewis, G.S., Godkin, J.D. \& Thatcher, W.W. (1985) Characterization of proteins produced in vitro by periattachment bovine conceptuses. Biol. Reprod. 32, 681-693.

Basu, S. \& Kindahl, H. (1987) Inhibitor of prostaglandin biosynthesis in the bovine endometrium during estrous cycle and early pregnancy. Theriogenology 28 , 175-193.

Biggers, B.G., Geisert, R.D., Wettemann, R.P. \& Buchanan, D.S. (1987) Effect of heat stress on early embryonic development in the beef cow. J. Anim. Sci. 64, 1512-1518.

Bowler, K., Duncan, C.J., Gladwell, R.T. \& Davison, T.F. (1973) Cellular heat injury. Comp. Biochem. Physiol. 45A, 441-450.

Calderwood, S.K., Stevenson, M.A. \& Hahn, G.M. (1985) Cyclic AMP and the heat shock response in chinese hamster ovary cells. Biochem. Biophys. Res. Commun. 126, 911-916.

Calderwood, S.K., Stevenson, M.A. \& Hahn, G.M. (1987) Heat stress stimulates inositol triphosphate release and phosphorylation of phosphoinositides in $\mathrm{CHO}$ and Balb C 3T3 cells. J. Cell. Physiol. 130, 369-376.

Fairclough, R.J., Smith, J.F. \& McGowen, L.T. (1981) Prolongation of the oestrous cycle in cows and ewes after passive immunization with PGF antibodies. $J$. Reprod. Fert. 62, 213-219.

Flint, A.P.F., Leat, W.M.F., Sheldrick, E.L. \& Stewart, H.J. (1986) Stimulation of phosphoinositide hydrolysis by oxytocin and the mechanism by which oxytocin controls prostaglandin synthesis in the ovine endometrium. Biochem. J. 237, 797-805.

Gross, T.S., Thatcher, W.W., Hansen, P.J., Johnson, J.W. \& Helmer, S.D. (1988a) Presence of an intracellular endometrial inhibitor of prostaglandin synthesis during early pregnancy in the cow. Prostaglandins 35, $359-378$.

Gross, T.S., Thatcher, W.W. \& Hansen, P.J. (1988b) Prostaglandin secretion by perifused bovine endometrium: secretion towards the myometrial and luminal sides at Day 17 post-estrus as altered by pregnancy. Prostaglandins 35, 343-358.

Gwazdauskas, F.C., Thatcher, W.W. \& Wilcox, C.J. (1973) Physiological, environmental, and hormonal factors at insemination which may affect conception. J. Dairy Sci. 56, 873-877.

Hahn, G.M. (1982) Hyperthermia and Cancer. Plenum Press, New York.

Hansel, W., Shemesh, M., Hixon, J. \& Lukaszewska, J. (1975) Extraction, isolation and identification of a luteolytic substance from bovine endometrium. Biol. Reprod. 13, 30-37.

Hoagland, T.A. \& Wettemann, R.P. (1984) Influence of elevated ambient temperature after breeding on plasma corticoids, estradiol and progesterone in gilts. Theriogenology 22, 15-24.

Ingraham, R.M., Gillette, D.D. \& Wagner, W.E. (1974) Relationship of temperature and humidity to conception rate of Holstein cows in subtropical climate. $J$. Dairy Sci. 57, 476481 .

Kennedy, T.G. (1985) Evidence for the involvement of prostaglandins throughout the decidual cell reaction in the rat. Biol. Reprod. 33, $140-146$.

Knickerbocker, J.J., Thatcher, W.W., Bazer, F.W., Drost, M., Barron, D.H., Fincher, K.D. \& Roberts, R.M. (1986a) Proteins secreted by Day-16 to -18 bovine conceptuses extend corpus luteum function in cows. J. Reprod. Fert. 77, 381-391.

Knickerbocker, J.J., Thatcher, W.W., Foster, D.B., Wolfenson, D., Bartol, F.F. \& Caton, D. (1986b) Uterine prostaglandin and blood flow responses to estradiol-17 $\beta$ in cyclic cattle. Prostaglandins 31, 757-776.

Lacroix, M.C. \& Kann, G. (1983) Discriminating analysis of in vitro prostaglandin release by myometrial and luminal sides of the ewe endometrium. Prostaglandins 25, 853-869.

Lafrance, M. \& Goff, A.K. (1985) Effect of pregnancy on oxytocin induced release of prostaglandin F-2 $\alpha$ in heifers. Biol. Reprod. 33, 1113-1119.

Lauderdale, J.W. (1974) Distribution and biological effects of prostaglandins. J. Anim. Sci. 38 (Suppl 1), 22-30.

Lewis, G.S., Thatcher, W.W., Bliss, E.L., Drost, M. \& Collier, R.J. (1984) Effects of heat stress during pregnancy on postpartum reproductive changes in Holstein cows. J. Anim. Sci. 58, 174-186.

Nancarrow, C.D., Buckmaster, J., Chamley, W., Cummins, L., Drinen, J.P., Findlay, J.K., Goding, J.R., Restall, B.J., Schneider, W. \& Thorburn, G.D. (1973) Hormone changes around oestrus in the cow. J. Reprod. Fert. 32, 320-321, Abstr.

Oyedipe, E.O., Gustafsson, B. \& Kindahl, H. (1984) Blood levels of progesterone and 15-keto-13,14dihydro prostaglandin F-2 $\alpha$ during the estrous cycle of oxytocin treated cows. Theriogenology 22, 329-339.

Putney, D.J., Drost, M. \& Thatcher, W.W. (1986) Embryonic development in dairy cattle exposed to elevated temperature between days 1 to 7 post insemination. Biol. Reprod. 34 (Suppl 1), 100, Abstr.

Putney, D.J., Malayer, J.R., Gross, T.S., Hansen, P.J., Thatcher, W.W. \& Drost, M. (1987) Heat shock induced alterations in prostaglandin and protein secretion by bovine conceptuses and uterine endometrium. Biol. Reprod. 36 (Suppl. 1), 314, Abstr.

SAS User's Guide (1985) Statistics. SAS Institute Inc Cary NC.

Shemesh, M. \& Hansel, W. (1975) Levels of prostaglan$\operatorname{din} \mathbf{F}$ (PGF) in bovine endometrium, uterine venous, ovarian arterial and jugular plasma during the estrous cycle. Proc. Soc. exp. Biol. Med. 148, 123-126.

Thatcher, W.W. (1974) Effects of season, climate and temperature on reproduction and lactation. J. Dairy Sci. 57, 360-368.

Thatcher, W.W. \& Chenault, J.R. (1976) Rreproductive 
and physiological responses to exogenous prostaglandin $\mathrm{F}_{2}$. J. Dairy Sci. 59, 1366-1375.

Thatcher, w.w., Wolfenson, D., Curl, J.S., Rico, L.E., Knickerbocker, J.J., Bazer, F.W. \& Drost, M. (1984) Prostaglandin dynamics associated with development of the bovine conceptus. Anim. Reprod. Sci. 7, $149-176$.
Wettemann, R.P., Baxer, F.W., Thatcher, W.W. \& Hoagland, T.A. (1984) Environmental influences on embryonic mortality. Proc. 10th Int. Congr. Anim. Reprod. \& A.I., Urbana-Champaign, Vol. V.XIII, 26-32.

Received 17 February 1988 